\title{
Inheritance of tristyly in Oxalis tuberosa (Oxalidaceae)
}

\author{
B. R. TROGNITZ* \& M. HERMANN \\ International Potato Centre, Av. La Universidad 795, Lima 12, Peru
}

\begin{abstract}
Frequencies of floral morphs in progenies obtained from a complete set of diallelic crosses among three accessions of tristylous, octoploid oca (Oxalis tuberosa) were used for a Mendelian analysis of floral morph inheritance. The frequencies observed had the best fit to a model of tetrasomic inheritance with two diallelic factors, $S, s$ and $M, m$, with $S$ being epistatic over $M$. No explanation could be found for the unexpected formation of a small percentage of short-styled individuals in crosses between the mid-styled and the long-styled parent. For the acceptance of models of disomic and octosomic inheritance several additional assumptions would have to be made and therefore these modes of inheritance are less likely. Dosage-dependent inheritance of floral morph was rejected. Only a small frequency $(36 \%)$ of the cross progenies flowered, in contrast to the greater propensity for flowering of $O$. tuberosa accessions held at gene banks.
\end{abstract}

Keywords: heterostyly, inheritance of tristyly, oca, Oxalis tuberosa, tetrasomic inheritance.

\section{Introduction}

The vegetatively propagated tuber crop oca (Oxalis tuberosa Mol.) is used by subsistence farmers in the high Andes. It is a secondary staple food in communities depending principally on the potato. Several thousand clonal accessions are held at gene banks, and their maintenance is under risk and scrutiny due to a variety of factors. Alternative conservation of the oca gene pool as botanical seed was proposed by Carrión et al. (1995), and first steps were undertaken to produce seed (Carrión, 1995; Quiñones, 1997) and to investigate the feasibility of the gene pool's conservation as seed (Trognitz et al., $1998)$. Oca is the only known octoploid $(2 n=8 \mathrm{x}=64)$ member of the Oxalis tuberosa alliance group of species that comprise a polyploid series between $2 \mathrm{x}$ and $8 \mathrm{x}$ (De Azkue \& Martínez, 1990). It is botanically isolated, as the crop's wild ancestors are unknown. Oca expresses tristyly, and its three floral morphs, short- (S), mid- (M) and long-styled (L), can be used conveniently as markers for sexual cross compatibility. The seed set depends on the specific combination in crosses of the different floral morphs. Out of 18 cross combinations possible, the most fertile are the legitimate pollinations, in which pollen from an anther of specific length is transferred to a stigma of the same length (Darwin, 1877). The six legitimate

*Correspondence and present address: ARCS (Austrian Research Centre Seibersdorf), Environment and Life Sciences, A-2444 Seibersdorf, Austria. E-mail: bodo.trognitz@arcs.ac.at pollinations are (morph of female parent $\times$ anther level of pollen parent): $\mathrm{S} \times \mathrm{sM}, \mathrm{S} \times \mathrm{sL}, \mathrm{M} \times \mathrm{mS}, \mathrm{M} \times \mathrm{mL}$, $\mathrm{L} \times 1 \mathrm{~S}, \mathrm{~L} \times 1 \mathrm{M}$. In addition, one illegitimate cross involving two oca morphs, $\mathrm{M} \times 1 \mathrm{~S}$, was found to produce seed at a quantity comparable to that obtained in legitimate pollinations (Trognitz et al., 1998).

For the tristylous species of the Oxalidaceae, Lythraceae and Pontederiaceae, a genetic model of floral morph determination has been proposed, in which the diallelic factor $S, s$ interacts epistatically with $M, m$. This model was put forward by Barlow (1923) and von Ubisch (1926), it was substantiated by Fisher \& Mather (1943), and it has been accepted for many other tristylous species (Lewis \& Jones, 1992). Under that model, genotypes carrying at least one copy of the dominant allele of the $S$ factor, which is epistatic over $M$, have a short-styled (S) phenotype. The M phenotype is produced by genotypes recessive at $S$ and dominant at $M$ (genotype of a diploid, ss $M$ ), and the double homozygous recessive genotype ( $\mathrm{ssmm}$ ) constitutes the $\mathrm{L}$ morph. Although this model accounts for the tristyly of most species investigated, it has been difficult to accommodate occasional reversal of the phenotype, such as in Oxalis articulata with long style inherited by the dominant $S$ and the short style being double homozygous recessive (reviewed by Lewis \& Jones, 1992). Complementary assumptions on the model have been made to better explain style morph segregation in specific populations of a few tristylous species (Leach, 1983; see also Barrett, 1992, p. 7). 
We investigated the inheritance of tristyly in O. tuberosa using a system of diallelic crosses between clonal oca accessions representing the three floral morphs. We could not raise subsequent crossing generations to confirm the hypotheses on inheritance presented. Knowledge of floral morph inheritance is important to better understand the phylogenetic relationship of oca with other species of Oxalis, to evaluate the feasibility of conservation through botanical seed, and to facilitate future breeding. The investigation addressed the following questions. How many factors are involved in the inheritance of tristyly in oca? Do these factors display epistatic relationships? Is the inheritance disomic, tetrasomic or octosomic? Is allele dosage important?

\section{Materials and methods}

Crosses were carried out between the short-styled (S) O.255.85, the mid-styled (M) O.267.85, and the longstyled (L) COC.429 accessions of oca that are described by Trognitz et al. (1998). These accessions were selected for their propensity to flower abundantly and their perfect self-incompatibility; no fruit formation was obtained after numerous self pollinations. All experiments were carried out at Santa Catalina near Quito, Ecuador (coordinates: $0^{\circ} 21^{\prime} \mathrm{S}, 78^{\circ} 33^{\prime} \mathrm{W}, 3050 \mathrm{~m}$ a.s.1.). The daylength is $12 \mathrm{~h}$ and temperature oscillates daily between $8^{\circ} \mathrm{C}$ and $20^{\circ} \mathrm{C}$, whereas seasonal differences are minimal. During 1996-97, several clonal plants of each accession were grown from tubers in pots in a greenhouse. Dormant tubers were immersed prior to planting in a 30-ppm $\mathrm{GA}_{3}$ (gibberellic acid) solution for $15 \mathrm{~min}$ to stimulate sprouting. Complex N-P-K fertilizer was applied every two weeks and pesticides were used when needed to control whitefly and aphids. The main stem of each juvenile plant was pruned to stimulate branching and to increase the number of inflorescences per plant.

For the three reciprocal pairs of diallelic crosses $(\mathrm{S} \times \mathrm{M}$ and $\mathrm{M} \times \mathrm{S}, \mathrm{S} \times \mathrm{L}$ and $\mathrm{L} \times \mathrm{S}$, and $\mathrm{M} \times \mathrm{L}$ and $\mathrm{L} \times \mathrm{M}$ ) sets of five plants prior to flowering of each of two clones were placed in a $2 \times 2 \mathrm{~m}$ pollination cabinet located within a screen house. The pollination cabinets were separated from each other by insect-proof plastic screens. At the onset of flowering, several solitary bumblebees (Bombus funebris) were put into a pollination cabinet. Quiñones (1997) identified Bombus funebris as an efficient insect pollinator of oca flowers. The bumblebees, which were captured outside, were cleaned using a fine brush and water, to ensure elimination of contaminant pollen. Sugar solution was provided as an additional food source, and the bumblebees were removed from the pollination cabinet after one week when they had cross-pollinated all flowers. Pollen originating from the pollinator's two anther levels contributed to each cross, as the flowers were not emasculated. Developing capsules were covered with a pergamine bag to secure the seed released from the selfdehiscing, mature capsule.

Seeds were harvested separately from each reciprocal cross parent and treated with fungicide. Dormancy was broken by immersing the seed overnight in $0.2 \% \mathrm{KNO}_{3}$ solution. The seeds were then germinated on moist filter paper in a Petri dish placed in a growth chamber at $18^{\circ} \mathrm{C}$. The $2-3 \mathrm{~cm}$ long seedling plants were cultivated in sterile substrate and later in pots in a greenhouse. The young plants were transferred to a field when their main stem was $20-30 \mathrm{~cm}$ tall. The irrigated field was sheltered with reinforced, transparent plastic foil to prevent damage of the plants by hail and rainstorms. We used a randomized six-block planting design. Each cross progeny was divided into six groups of equal numbers of plants, and each block in the field contained one such group per cross. All seedlings were individually labelled and their floral morph was determined on fully developed flowers, which emerged during an eight-month period. The relative position of the styles and stamens within the more than $10 \mathrm{~mm}$ long, pentameric oca flower is easily recognized. The frequencies of the individual floral morphs were subjected to $\chi^{2}$ analyses for homogeneity between reciprocal crosses and for deviation from segregations expected under models of two-locus inheritance. The models tested were (a) inheritance by two factors, $S, s$ and $M, m$, with $S$ epistatic over $M$ and full dominance of $S$ over $s$ and $M$ over $m$; (b) the same two-factor model, but assuming dosage effects of several dominant alleles at a locus.

\section{Results}

\section{Flowering ability}

Of 1518 plants grown, only 543 (36\%) flowered; the frequency was largest for the reciprocal crosses between $S$ and $M$ (46\% of all plants flowered), and smallest for crosses between $S$ and L (21\%; Table 1$)$. The majority of these plants flowered during a three-month period, at an age of 60-150 days, and about $25 \%$ of all plants that flowered developed a few flowers later, at an age of up to 10 months. Flowering was similar throughout all subsets of plants of a single cross, independently of its location within the six blocks $\times$ six crosses field design.

\section{Frequency of floral morphs}

There was no deviation from homogeneity of floral morph frequencies for the $\mathrm{S} \times \mathrm{M}, \mathrm{M} \times \mathrm{S}$ and $\mathrm{S} \times \mathrm{L}$, $\mathrm{L} \times \mathrm{S}$ pairs of reciprocal crosses (Table $1 ; \chi^{2}$-test statistics for homogeneity of reciprocal crosses). However, 
Table 1 Number of progeny grown within each of six diallelic cross combinations between three accessions of Oxalis tuberosa, number and frequency of progeny that flowered, and frequency of floral morphs obtained within each cross

\begin{tabular}{|c|c|c|c|c|c|}
\hline \multirow[b]{2}{*}{ Cross } & \multirow{2}{*}{$\begin{array}{l}\text { No. of } \\
\text { progeny grown }\end{array}$} & \multirow{2}{*}{$\begin{array}{l}\text { No. }(\% \text { of total) } \\
\text { of progeny flowering }\end{array}$} & \multicolumn{3}{|c|}{$\begin{array}{l}\text { Floral morph no. ( } \% \text { of flowering) } \\
\text { progeny obtained }\end{array}$} \\
\hline & & & $\mathrm{S}$ & M & $\mathrm{L}$ \\
\hline $\mathrm{S} \times \mathrm{M}$ & 300 & $132(44)$ & $69(52)$ & $51(39)$ & $12(9)$ \\
\hline $\mathrm{M} \times \mathrm{S}$ & 300 & $145(48)$ & $82(56)$ & $53(36)$ & $10(7)$ \\
\hline Total & & 277 (46) & $151(54)$ & $104(38)$ & $22(8)$ \\
\hline \multicolumn{6}{|c|}{ Heterogeneity between reciprocals: $\chi^{2}=0.708$, d.f. $=2, P>0.70$} \\
\hline $\mathrm{M} \times \mathrm{L}$ & 300 & $133(44)$ & $5(4)$ & $103(77)$ & 25 (19) \\
\hline $\mathrm{L} \times \mathrm{M}$ & 218 & 49 (24) & $10(20)$ & $28(57)$ & $11(22)$ \\
\hline Total & & $182(35)$ & $15(8)$ & $131(72)$ & $36(20)$ \\
\hline \multicolumn{6}{|c|}{ Heterogeneity between reciprocals: $\chi^{2}=14.32$, d.f. $=2, P>0.0007$} \\
\hline $\mathrm{S} \times \mathrm{L}$ & 300 & $64(21)$ & $39(61)$ & $2(3)$ & $23(36)$ \\
\hline $\mathrm{L} \times \mathrm{S}$ & 100 & $20(20)$ & $12(60)$ & $3(15)$ & $5(25)$ \\
\hline Total & & $84(21)$ & $51(61)$ & $5(6)$ & $28(33)$ \\
\hline \multicolumn{6}{|c|}{ Heterogeneity between reciprocals: $\chi^{2}=4.17$, d.f. $=2, P>0.12$} \\
\hline Grand total & 1518 & $543(36)$ & $217(40)$ & $240(44)$ & $86(16)$ \\
\hline
\end{tabular}

the $\mathrm{M} \times \mathrm{L}$ cross had floral morph proportions different from the $\mathrm{L} \times \mathrm{M}$ cross (Table 1 ). All six cross combinations produced plants of all three floral morphs, i.e. in several crosses, some individuals had a morphology that was not expected to arise under the two-locus model of inheritance of tristyly (see Tables 1-4). No plants with abnormal flowers (semi-homostyle; Lewis \& Jones, 1992, p. 130) were observed.

\section{Test of models of inheritance}

A $\chi^{2}$-test of goodness of fit of the floral morph frequencies obtained and proportions expected was carried out for each diallelic cross and for several possible parental genotypes. As each parental plant was used in four of the six diallelic crosses, the genotype under consideration for one parent had to be accepted for each of the four crosses in which this parent was used. According to these conditions, only one set of parental genotypes was found to be likely for each model of disomic, tetrasomic, and octosomic inheritance (Tables 2-4). However, these respective genotypes assumed were in accordance with the twofactor model only when the following assumptions were made:

Disomic inheritance (Table 2):

- The S parent is heterozygous at the $S$ locus, $S s \mathrm{~mm}$;

- The M parent is homozygous dominant at the $M$ locus, ss $M M$;

- The L parent is double homozygous recessive, ss mm;
- The long-styled plants obtained from the $\mathrm{S} \times \mathrm{M}$ and $\mathrm{M} \times \mathrm{S}$ crosses would have the genotype of a midstyled morph, ss $M m$ or ss $M M$;

- All short-styled individuals of the $\mathrm{M} \times \mathrm{L}$ and $\mathrm{L} \times \mathrm{M}$ crosses would have at least one dominant $M$ allele, ss Mm or ss MM;

- The few mid-styled individuals obtained from the $\mathrm{S} \times \mathrm{L}$ and $\mathrm{L} \times \mathrm{S}$ crosses should have the ss $\mathrm{mm}$ genotype of the long-styled morph.

Tetrasomic inheritance (Table 3):

- The S parent is simplex at the $S$ locus, Ssss mmmm;

- The M parent is duplex at the $M$ locus, ssss $M M m m$;

- The L parent is double homozygous recessive, ssss mmmm;

- In the $\mathrm{M} \times \mathrm{L}$ and $\mathrm{L} \times \mathrm{M}$ crosses, the few short-styled plants would have at least one dominant $M$ allele, ssss Mmmm;

- In the $\mathrm{S} \times \mathrm{L}$ and $\mathrm{L} \times \mathrm{S}$ crosses, the few mid-styled plants would have the L genotype, ssss mmmm.

Octosomic inheritance (Table 4):

- The S parent's genotype is simplex at both loci, Ssssssss Mmmmmmmm;

- The M parent is duplex at M, ssssssss MМтmтттті;

- The L parent is double homozygous recessive, ssssssss mmmmmmmm;

- $\mathrm{M} \times \mathrm{L}$ and $\mathrm{L} \times \mathrm{M}$ produced a few short-styled plants that should have at least one dominant $M$ allele, ssssssss Mmmmmmmm;

(c) The Genetics Society of Great Britain, Heredity, 86, 564-573. 
Table 2 Tests for goodness of fit of phenotype proportions observed with segregation ratios expected for a two-factor model of disomic inheritance of floral morph in oca assuming full dominance of $S$ over $s$ and $M$ over $m$ and epistasis of $S$ over $M$

\begin{tabular}{|c|c|c|c|c|c|c|c|c|c|}
\hline \multirow[b]{2}{*}{ Cross } & \multirow[b]{2}{*}{ Genetic model } & \multicolumn{6}{|c|}{ Phenotype frequencies among progeny } & \multirow[b]{2}{*}{$\chi^{2}$} & \multirow[b]{2}{*}{$P>$} \\
\hline & & \multicolumn{3}{|c|}{ Observed } & \multicolumn{3}{|c|}{ Expected } & & \\
\hline \multicolumn{2}{|c|}{ Crosses between $\mathrm{S}$ and $\mathrm{M}$} & $\mathrm{S}$ & \multicolumn{2}{|c|}{$\mathrm{M}+\mathrm{L} \dagger$} & $\mathrm{S}$ & \multicolumn{2}{|c|}{$M+L$} & & \\
\hline $\mathrm{S} \times \mathrm{M}$ & \multirow[t]{3}{*}{ Ss $m m \times s s M M$} & 69 & 63 & & 1 & \multicolumn{2}{|c|}{1} & 0.27 & $0.601, \mathrm{NS}$ \\
\hline $\mathrm{M} \times \mathrm{S}$ & & 82 & \multicolumn{2}{|l|}{63} & 1 & \multicolumn{2}{|l|}{1} & 2.49 & $0.114, \mathrm{NS}$ \\
\hline Total & & 151 & \multicolumn{2}{|l|}{126} & 1 & \multicolumn{2}{|l|}{1} & 2.26 & $0.133, \mathrm{NS}$ \\
\hline \multicolumn{2}{|c|}{ Crosses between $\mathrm{M}$ and $\mathrm{L}$} & $\mathrm{S}$ & M & $\mathrm{L}$ & $\mathrm{S}$ & M & $\mathrm{L}$ & & \\
\hline$M \times L$ & \multirow[t]{3}{*}{ ss $M M \times s s \mathrm{~mm}$} & 5 & 103 & 25 & 0 & 1 & 0 & & \\
\hline $\mathrm{L} \times \mathrm{M}$ & & 10 & 28 & 11 & 0 & 1 & 0 & & \\
\hline Total & & 15 & 131 & 36 & 0 & 1 & 0 & & \\
\hline \multicolumn{2}{|c|}{ Crosses between $\mathrm{S}$ and $\mathrm{L}$} & $\mathrm{S}$ & \multicolumn{2}{|c|}{$M+L$} & $\mathrm{~S}$ & \multicolumn{2}{|c|}{$\mathrm{M}+\mathrm{L}$} & & \\
\hline $\mathrm{S} \times \mathrm{L}$ & Ss $m m \times s s m m$ & 39 & \multirow{2}{*}{\multicolumn{2}{|c|}{$\begin{array}{l}25 \\
8\end{array}$}} & 1 & \multirow{2}{*}{\multicolumn{2}{|c|}{$\begin{array}{l}1 \\
1\end{array}$}} & 3.06 & $0.080, \mathrm{NS}$ \\
\hline $\mathrm{L} \times \mathrm{S}$ & & 12 & & & 1 & & & 0.80 & $0.371, \mathrm{NS}$ \\
\hline Total & & 51 & \multicolumn{2}{|c|}{33} & 1 & \multicolumn{2}{|c|}{1} & 3.86 & $0.049 *$ \\
\hline
\end{tabular}

$\dagger$ The phenotypic classes, $\mathrm{M}$ and $\mathrm{L}$ were pooled (see Table 1).

$* P<0.05$.

NS, not significant.

Table 3 Tests for goodness of fit of phenotype proportions observed with segregation ratios expected for a two-factor model of tetrasomic inheritance of the floral morph in oca assuming full dominance of $S$ over $s$ and $M$ over $m$ and epistasis of $S$ over $M$

\begin{tabular}{|c|c|c|c|c|c|c|c|c|c|}
\hline \multirow[b]{2}{*}{ Cross } & \multirow[b]{2}{*}{ Genetic model } & \multicolumn{6}{|c|}{ Phenotype frequencies among progeny } & \multirow[b]{2}{*}{$\chi^{2}$} & \multirow[b]{2}{*}{$P>$} \\
\hline & & \multicolumn{3}{|c|}{ Observed } & \multicolumn{3}{|c|}{ Expected } & & \\
\hline \multicolumn{2}{|c|}{ Crosses between $\mathrm{S}$ and $\mathrm{M}$} & $\mathrm{S}$ & M & $\mathrm{L}$ & $\mathrm{S}$ & $\mathrm{M}$ & $\mathrm{L}$ & & \\
\hline $\mathrm{S} \times \mathrm{M}$ & Ssss $\mathrm{mmmm} \times$ ssss $M M m m$ & 69 & 51 & 12 & 6 & 5 & 1 & 0.518 & $0.771, \mathrm{NS}$ \\
\hline $\mathrm{M} \times \mathrm{S}$ & & 82 & 53 & 10 & 6 & 5 & 1 & 2.514 & $0.284, \mathrm{NS}$ \\
\hline Total & & 151 & 104 & 22 & 6 & 5 & 1 & 2.308 & $0.315, \mathrm{NS}$ \\
\hline \multicolumn{2}{|c|}{ Crosses between $\mathrm{M}$ and $\mathrm{L}$} & \multicolumn{2}{|c|}{$\mathrm{S}+\mathrm{M} \dagger$} & $\mathrm{L}$ & \multicolumn{2}{|c|}{$\mathrm{S}+\mathrm{M}$} & $\mathrm{L}$ & & \\
\hline $\mathrm{M} \times \mathrm{L}$ & ssss $M M m m \times$ ssss $\mathrm{mmmm}$ & \multicolumn{2}{|c|}{108} & 25 & \multicolumn{2}{|c|}{5} & 1 & 0.43 & $0.509, \mathrm{NS}$ \\
\hline $\mathrm{L} \times \mathrm{M}$ & & \multicolumn{2}{|c|}{38} & 11 & \multicolumn{2}{|c|}{5} & 1 & 1.18 & $0.277, \mathrm{NS}$ \\
\hline Total & & \multicolumn{2}{|c|}{146} & 36 & \multicolumn{2}{|c|}{5} & 1 & 1.27 & $0.259, \mathrm{NS}$ \\
\hline \multicolumn{2}{|c|}{ Crosses between $\mathrm{S}$ and $\mathrm{L}$} & \multicolumn{3}{|c|}{$M+L$} & \multicolumn{3}{|c|}{$\mathrm{M}+\mathrm{L}$} & & \\
\hline $\mathrm{S} \times \mathrm{L}$ & Ssss mmmm $\times$ ssss $\mathrm{mmmm}$ & \multirow{2}{*}{\multicolumn{3}{|c|}{$\begin{array}{l}39 \\
12\end{array}$}} & \multirow{2}{*}{\multicolumn{3}{|c|}{$\begin{array}{l}1 \\
1\end{array}$}} & 3.06 & $0.080, \mathrm{NS}$ \\
\hline $\mathrm{L} \times \mathrm{S}$ & & & & & & & & 0.80 & $0.371, \mathrm{NS}$ \\
\hline \multicolumn{2}{|l|}{ Total } & \multicolumn{3}{|l|}{51} & \multicolumn{3}{|c|}{1} & 3.86 & $0.049^{*}$ \\
\hline
\end{tabular}

$\dagger$ Two classes, $\mathrm{S}$ and $\mathrm{M}$ or $\mathrm{M}$ and $\mathrm{L}$ were pooled (see Table 1).

$* P<0.05$.

NS, not significant.

- $\mathrm{S} \times \mathrm{L}$ and $\mathrm{L} \times \mathrm{S}$ produced an excess of $\mathrm{L}$ individuals and too few $\mathrm{M}$ plants. The $\mathrm{S}$ morph would consist in part of plants that are genetically $\mathrm{M}$ (genotypes assumed: ssssssss Mmmmmmmm or ssssssss MMтmmmmm).

Models of allele dosage-dependent inheritance None of the above models of dominant inheritance could fully account for the occurrence of plants of all three floral morphs in all cross progenies. Therefore, several models of dosage-dependent expression of tristyly under octosomic inheritance were tested. Octoploid oca can have up to 81 different genotypes (for dominant inheritance: 72 genotypes for the $\mathrm{S}$ morph, eight for $\mathrm{M}$, and one for L) and there are a large number of possibilities for allele dosage-dependent expression of a specific floral morph. Therefore, it was necessary to test a few selected models of dosage-dependent phenotype expression that seemed

(C) The Genetics Society of Great Britain, Heredity, 86, 564-573. 
Table 4 Tests for goodness of fit of phenotype proportions observed with segregation ratios expected for variants of a two-factor model of octosomic inheritance of the floral morph in oca assuming full dominance of $S$ over $s$ and $M$ over $m$ and epistasis of $S$ over $M$

\begin{tabular}{|c|c|c|c|c|c|c|c|c|c|c|c|}
\hline \multirow[b]{3}{*}{ Cross } & \multirow[b]{3}{*}{ Variant of genetic model $\dagger$} & \multicolumn{8}{|c|}{ Phenotype frequencies among progeny } & \multirow[b]{3}{*}{$\chi^{2}$} & \multirow[b]{3}{*}{$P>$} \\
\hline & & \multicolumn{4}{|c|}{ Observed } & \multicolumn{4}{|c|}{ Expected } & & \\
\hline & & $\mathrm{S}$ & $\mathrm{S}+\mathrm{M} \ddagger$ & M & $\mathrm{L}$ & $\mathrm{S}$ & $\mathrm{S}+\mathrm{M}$ & M & $\mathrm{L}$ & & \\
\hline \multicolumn{12}{|c|}{ Crosses between $\mathrm{S}$ and $\mathrm{M}$} \\
\hline $\mathrm{S} \times \mathrm{M}$ & Model 1 , not rejected & 69 & & 51 & 12 & 28 & & 25 & 3 & 4.64 & $0.098, \mathrm{NS}$ \\
\hline $\mathrm{M} \times \mathrm{S}$ & Ssssssss Mmтmтmmm $\times$ & 82 & & 53 & 10 & 28 & & 25 & 3 & 4.01 & $0.134, \mathrm{NS}$ \\
\hline Total & ssssssss MMmтmmmm & 151 & & 104 & 22 & 28 & & 25 & 3 & 7.71 & $0.021 *$ \\
\hline $\mathrm{S} \times \mathrm{M}$ & Model 2, not rejected & 69 & & 51 & 12 & 4 & & 3 & 1 & 1.41 & $0.494, \mathrm{NS}$ \\
\hline $\mathrm{M} \times \mathrm{S}$ & Ssssssss Mmmmтmmm $\times$ & 82 & & 53 & 10 & 4 & & 3 & 1 & 4.92 & $0.085, \mathrm{NS}$ \\
\hline Total & ssssssss Mmmmmmmm & 151 & & 104 & 22 & 4 & & 3 & 1 & 5.73 & $0.056, \mathrm{NS}$ \\
\hline $\mathrm{S} \times \mathrm{M}$ & Model 3, rejected & 69 & & 51 & 12 & 2 & & 1 & 1 & 23.32 & 0 **** \\
\hline $\mathrm{M} \times \mathrm{S}$ & Ssssssss mmmmmmmm $\times$ & 82 & & 53 & 10 & 2 & & 1 & 1 & 27.99 & $0 * * *$ \\
\hline Total & ssssssss Mmmmmmmm & 151 & & 104 & 22 & 2 & & 1 & 1 & 50.81 & $0 * * *$ \\
\hline \multicolumn{12}{|c|}{ Crosses between $\mathrm{M}$ and $\mathrm{L}$} \\
\hline $\mathrm{M} \times \mathrm{L}$ & Model 1.a, not rejected & $-\S$ & & 103 & 25 & & & 11 & 3 & 0.27 & $0.600, \mathrm{NS}$ \\
\hline $\mathrm{L} \times \mathrm{M}$ & ssssssss MMmтmmmm $\times$ & - & & 28 & 11 & & & 11 & 3 & 1.06 & $0.302, \mathrm{NS}$ \\
\hline Total & ssssssss mmтmmmmmm & - & & 131 & 36 & & & 11 & 3 & 0.001 & $0.967, \mathrm{NS}$ \\
\hline $\mathrm{M} \times \mathrm{L}$ & Model 1.b, not rejected & & 108 & & 25 & & 11 & & 3 & 0.547 & $0.459, \mathrm{NS}$ \\
\hline $\mathrm{L} \times \mathrm{M}$ & ssssssss MMтттттm $\times$ & & 38 & & 11 & & 11 & & 3 & 0.03 & $0.861, \mathrm{NS}$ \\
\hline Total & ssssssss mmmmmmmm & & 146 & & 36 & & 11 & & 3 & 0.293 & $0.587, \mathrm{NS}$ \\
\hline $\mathrm{M} \times \mathrm{L}$ & Model 2, rejected & 5 & & 103 & 25 & 0 & & 1 & 1 & - & $0 * * *$ \\
\hline $\mathrm{L} \times \mathrm{M}$ & ssssssss Mmmmmmmm $\times$ & 10 & & 28 & 11 & 0 & & 1 & 1 & - & $0 * * *$ \\
\hline Total & ssssssss mmmmmmmm & 15 & & 131 & 36 & 0 & & 1 & 1 & - & $0^{* * *}$ \\
\hline \multicolumn{12}{|c|}{ Crosses between $\mathrm{S}$ and $\mathrm{L}$} \\
\hline $\mathrm{S} \times \mathrm{L}$ & Model 1.a, rejected & 39 & & 2 & 23 & 2 & & 1 & 1 & 16.84 & $0 * * *$ \\
\hline $\mathrm{L} \times \mathrm{S}$ & Ssssssss Mmmmmmmm $\times$ & 12 & & 3 & 5 & 2 & & 1 & 1 & 1.20 & $0.548, \mathrm{NS}$ \\
\hline Total & ssssssss mmmmmmmm & 51 & & 5 & 28 & 2 & & 1 & 1 & 16.45 & $0 * * *$ \\
\hline $\mathrm{S} \times \mathrm{L}$ & Model 1.b, not rejected & 39 & & -9 & 23 & 2 & & & 1 & 0.39 & $0.529, \mathrm{NS}$ \\
\hline $\mathrm{L} \times \mathrm{S}$ & Ssssssss Mmтmтmmm $\times$ & 12 & & - & 5 & 2 & & & 1 & 0.11 & $0.731, \mathrm{NS}$ \\
\hline Total & ssssssss mmmmmmmm & 51 & & - & 28 & 2 & & & 1 & 0.15 & $0.690, \mathrm{NS}$ \\
\hline $\mathrm{S} \times \mathrm{L}$ & Model 1.c, not rejected & & 41 & & 23 & & 3 & & 1 & 4.08 & $0.043^{*}$ \\
\hline $\mathrm{L} \times \mathrm{S}$ & Ssssssss Mmтmmтmm $\times$ & & 15 & & 5 & & 3 & & 1 & 0 & $1, \mathrm{NS}$ \\
\hline Total & ssssssss mmmmmmmm & & 56 & & 28 & & 3 & & 1 & 3.11 & $0.077, \mathrm{NS}$ \\
\hline
\end{tabular}

$\dagger$ Three genetic models of inheritance were tested, model 1 is not rejected under assumptions (for $\mathrm{S} \times \mathrm{L}$ and $\mathrm{L} \times \mathrm{S}$ crosses) of either lethality of one sort of gametes (model 1.b) or expression of the $\mathrm{S}$ morph by the genotype of the $\mathrm{M}$ morph (model 1.c; see also Discussion).

$\$$ The phenotypic classes $\mathrm{S}$ and $\mathrm{M}$ were pooled (compare Table 1).

§Plants expressing the $\mathrm{S}$ morph were omitted from the analysis.

$\uparrow \mathrm{M}$ plants were omitted from the analysis (assuming lethality of the genotype sssssss Mmmmmmmm).

$* P<0.05 ; * * * P<0.001 ; \mathrm{NS}$, not significant.

most likely to apply. The following parental genotypes and their corresponding hypothetical phenotypes were tested:

1 short-styled =SSM; $\quad$ mid-styled $=S M M, \quad$ longstyled $=s m$ or $M M$;

2 short-styled $=S M, \quad$ mid-styled $=S M M M, \quad$ longstyled $=s m$;
3 short-styled $=S M$, mid-styled $=S M M M M$, longstyled $=s m$.

Each of these sets of genotypes was tested in two steps for its goodness of fit with the style proportions expected. The first step was to declare specific, expected recombinant genotypes to produce one of the three flower phenotypes, and in the second step, these declared 
genotype-phenotype relationships were tested on the floral morph proportions obtained in the crosses. For a set of genotypes to be accepted, it had to account for the proportions of phenotypes observed in all crosses.

In the following it will be explained how set no. 1 (above) of alternative parental genotypes was derived and tested for its validity.

As unexpected short-styled plants were obtained from the $\mathrm{M} \times \mathrm{L}$ and $\mathrm{L} \times \mathrm{M}$ crosses (Tables 1 and 4 ), it was assumed that the mid parent was duplex at $M$ and simplex at $S$ (assumed genotype Ssssssss MMmmmmmm; short-notation $S M M$ ). When $S$ and $M$ are not linked, this genotype gives rise to six gametic classes: $21 S M M$, $56 S M, 21 S, 21 M M, 56 M$, and $21 \mathrm{sm}$. The $\mathrm{L}$ parent was assumed to be double homozygous recessive $(\mathrm{sm})$, thus producing just one sort of gamete, $s m$. When it is assumed that genotype $S M M$ produces a mid-styled phenotype and $s m$ is long-styled, then $M M$ and $M$ could be also mid-styled, $S$ could be short-styled and $S M$ could be either short- or mid-styled. The morph frequencies resulting from six models in which specific genotypes were assigned to a specific flower phenotype were compared with the proportions obtained (Table 5, upper section). One model fitted the proportions observed for the reciprocal crosses between $\mathrm{M}$ and $\mathrm{L}$ and between $\mathrm{S}$ and $\mathrm{M}$ (Table 5; model 1, upper and middle section), in which genotype $S M$ produced a midstyled phenotype. However, for the crosses between $S$ and L (Table 5; model 1, bottom section), the $S M$ genotype would account for a long-styled phenotype, as this genotype-phenotype relationship was the only one not rejected by the $\chi^{2}$-test. Because it is unlikely that one genotype could produce different phenotypes depending on the specific cross this model of dosage-dependent floral morph inheritance was rejected.

The other two models of dosage-dependent inheritance were also tested in the way described above and none of them reasonably accounted for the floral morph proportions obtained. It appeared not useful to test further models, as this would have required a departure from the Fisher \& Mather (1943) concept of two-factor inheritance with epistasis of one factor over the other.

\section{Discussion}

\section{Flowering ability}

The percentage of cross progenies that flowered (36\%) was much smaller than the percentage of clones flowering of a large sample of oca collections when these were grown at Quito, Ecuador, under the 12-h daylength (Table 6). The oca gene pools of the different countries listed in Table 6 could be specifically adapted to photoperiods of either 12 or $13 \mathrm{~h}$. This is supported by observations in Puno, southern Peru (approximate day length $13 \mathrm{~h}$ ), where more than $90 \%$ of all indigenous oca varieties grown by farmers flower in every year (R. Valdivia, University of Puno, Puno, Peru 1997, personal communication). As the cross progenies investigated were derived from parental clones originating in southern Peru, the 12-h day at our experimental site at the equator could have retarded flowering of the cross progenies. Alternatively, farmers who selected the native varieties, which represent the gene bank accessions may have used flowering as a selection criterion, or the ability to flower may be linked to an unknown character of agricultural importance that was selected for. It was assumed that the different crosses produced different rates of flowering owing to the specific combining abilities of each of the three parental accessions used, and that there was no genetic linkage with genes responsible for tristyly.

\section{Frequency and inheritance of floral morphs}

The floral morph frequencies obtained within the six diallelic crosses are in general agreement with the model of inheritance by two diallelic factors, that has been accepted for Lythrum salicaria (Fisher \& Mather, 1943) and several Oxalis species (Lewis \& Jones, 1992). There was heterogeneity of the floral morph frequencies between the $\mathrm{M} \times \mathrm{L}$ and $\mathrm{L} \times \mathrm{M}$ crosses (Table 1). The small number of $49 \mathrm{~L} \times \mathrm{M}$ individuals that flowered may have prevented the $\chi^{2}$-test from detecting homogeneity. For each reciprocal cross the morph frequencies obtained were in accordance with specific variants of the two-factor model (Tables 3 and 4). Maternal inheritance of the floral morph is not likely; it then should have occurred throughout all crosses involving the $\mathrm{L}$ or the $\mathrm{M}$ parent.

A variation of the two-locus model specific for oca may be indicated by the occurrence of all three floral morphs in all six diallelic crosses. The $\mathrm{S}$ morph unexpectedly occurred in $\mathrm{M} \times \mathrm{L}$ and $\mathrm{L} \times \mathrm{M}$ progenies, and the $\mathrm{S} \times \mathrm{L}$ and $\mathrm{L} \times \mathrm{S}$ crosses gave rise to all three flower phenotypes even when the assumed parental genotypes predicted only two phenotypes among the offspring (Tables 2 and 3). Therefore, it was necessary to test models for both dominant (allo- and autopolyploid) and allele dosage-dependent inheritance of floral morph formation in the octoploid, O. tuberosa.

Disomic inheritance could occur when the plants possessed genomes of four diploid, or two diploid and one tetraploid, putative ancestors. One of the diploid ancestors would have contributed the genetic factors that determine tristyly. Several possible genetic models were tested and the only model that was not rejected by the $\chi^{2}$-tests is given in Table 2 . However, several 


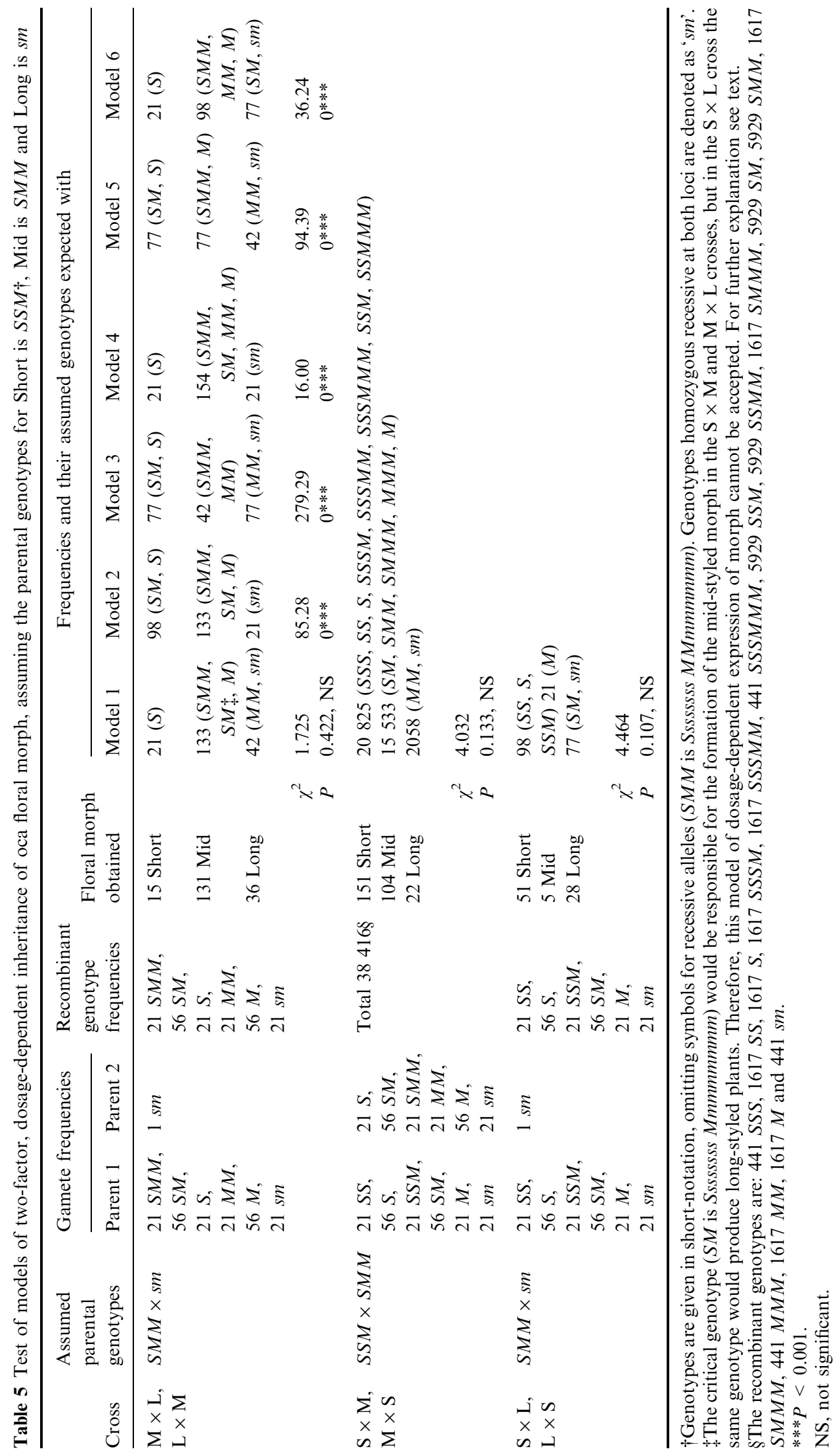

(c) The Genetics Society of Great Britain, Heredity, 86, 564-573. 
Table 6 Frequency of clonal oca collections flowering at Quito during a 4-year period, arranged by geographical area of accession provenance

\begin{tabular}{lcrr}
\hline & $\begin{array}{c}\text { Latitude of } \\
\text { collection } \\
\text { sites }\left({ }^{\circ} \mathrm{S}\right)\end{array}$ & & \multicolumn{2}{c}{ Oca accessions } \\
\cline { 3 - 4 } Provenance & $0-4$ & Total & Flowering \\
\hline Ecuador & $7-16$ & 97 & $96(99 \%)$ \\
Peru & $17-20$ & 79 & $144(75 \%)$ \\
Bolivia & $22-24$ & 58 & $63(80 \%)$ \\
Argentina & $18-23$ & 7 & $1(64 \%)$ \\
Chile & 43 & 1 & $0(0 \%)$ \\
Chile (Chiloe & & & \\
Island) & & & \\
\hline
\end{tabular}

additional assumptions must be made to fully justify the figures observed. In crosses involving $\mathrm{S}$ and $\mathrm{M}$, the $\mathrm{L}$ plants obtained would have to be assumed to possess at least one copy of the dominant $M$ allele (Tables 1 and 2). Most disturbing is the unexpected occurrence of relatively many individuals representing both the $\mathrm{S}$ and $\mathrm{L}$ morphs, in the cross progenies of $\mathrm{M} \times \mathrm{L}$ and $\mathrm{L} \times \mathrm{M}$. Under the model given in Table 2, only the $\mathrm{M}$ morph would be expected to arise from these crosses. For these reasons, it appears unlikely that the floral heteromorphism in oca has a disomic inheritance pattern.

For tetrasomic inheritance, the crop should have at least one tetraploid ancestor that contributed the factors for heterostyly. The style morph frequencies obtained with crosses involving $\mathrm{S}$ and $\mathrm{M}$ are in perfect agreement with this model (Table 3). However, for the crosses between $\mathrm{M}$ and $\mathrm{L}$, it must be assumed that a few plants that are genetically $\mathrm{M}$ (or L), expressed a short-styled phenotype. In the crosses between $\mathrm{S}$ and $\mathrm{L}$, a few $\mathrm{L}$ genotypes (double homozygous recessive) would have the $\mathrm{M}$ phenotype, and there was also an excess of $\mathrm{S}$ plants (Table 3; marginal significance of the pooled frequencies $\chi^{2}=3.86, P>0.049$ ). A plant of an unexpected morph was also obtained in crosses between Decodon verticillatus plants by Eckert \& Barrett (1993). These authors believed that this plant was a contaminant. The short-styled oca progenies in our reciprocal $\mathrm{M} \times \mathrm{L}$ crosses are unlikely to have resulted from contamination. The cross pollinations were carried out under strictly controlled conditions, and the sticky and heavy oca pollen is not amenable to wind dispersal. An alternative explanation for the occurrence of the $\mathrm{S}$ morph could be an additional modifying factor of low penetrance that caused plants of an $M$ genotype to develop into the $\mathrm{S}$ morph. In an auto-alloploid, the presence of specific genes that determine the expression of a trait may make invisible, or silence, the corresponding genes on the homeologous genome(s). When a specific gene is missing from the genome that determines trait expression, it may be substituted by its corresponding homeologous gene(s). In our $\mathrm{M} \times \mathrm{L}$ cross, the $S$ locus was homozygous recessive for both parents. A putative homeologous counterpart of the $S$ locus may have carried a dominant allele that became functional, resulting in the formation of short-styled plants. We did however, not find an alternative genetic model of inheritance that could reasonably describe the occurrence of this additional flower phenotype.

For octosomic inheritance, results of $\chi^{2}$-tests on three genetic models are provided in Table 4 . Two of the models were rejected as they were in disagreement with the results of one or more crosses. The figures obtained in the crosses could be fitted to Model 1 of Table 4 when the following assumptions were made. The short-styled parent would carry both $S$ and $M$ in simplex, the mid parent must then be duplex at the $M$ locus (ssssssss MMmmmmmm) and the long parent would be double homozygous recessive. Segregation ratios expected under this assumption were in accord with the figures observed in all crosses between $\mathrm{S}$ and $\mathrm{M}$ and between $\mathrm{M}$ and $\mathrm{L}$. The pooled frequencies obtained with the $\mathrm{S} \times \mathrm{M}$ and $\mathrm{M} \times \mathrm{S}$ crosses were marginally significant $\left(\chi^{2}=7.71, P>0.021\right)$, but each of the two separate crosses fitted the ratios expected. However, to fit the $\mathrm{S} \times \mathrm{L}$ and $\mathrm{L} \times \mathrm{S}$ cross data, additional assumptions had to be made. Under-representation of mid-styled progenies could have resulted from a putative lethality factor (Table 4, lower part, model 1.b.) or from an unknown mechanism that caused $M$ genotypes to express the short morph (Table 4, lower part, model 1.c). Because many additional, complicated assumptions had to be made to validate the genetic model, octosomic inheritance seems unlikely.

In polyploid oca, it may be assumed that the copy number of dominant alleles at either the $S$ or the $M$ locus influenced the floral morph expression in a quantitative fashion. However, none of the models assuming ( $\mathrm{S}$ or $\mathrm{M})$ dosage-dependent expression of flower phenotype fitted the data obtained (Table 5).

\section{Evidence for tetrasomic inheritance and implications for breeding and genetics}

As has been outlined above, tetrasomic inheritance of the floral morph in $O$. tuberosa has the best fit with our observations. Therefore, it is possible that oca is an auto-alloploid. Meiotic or mitotic doubling of the chromosome number of a single diploid may have led to the formation of a putative tetraploid ancestor, which subsequently fused with two different diploids or with another tetraploid, to form $O$. tuberosa. An allopolyploid origin of this species is also supported by 
observations on sequence diversity of the internal transcribed spacer of nuclear ribosomal DNA (Emshwiller \& Doyle, 1998b) and by DNA sequences of chloroplastactive nuclear encoded glutamine synthetase (Emshwiller \& Doyle, 1998a). Cytological monitoring of occurrence of chromosomal multivalents in dividing cells could give further insight into whether oca is autoalloploid. Such analysis is however, difficult because of the small size and the large number $(8 x=64)$ of the chromosomes of this species (e.g. De Azkue \& Martínez, 1990). An indirect indicator of the degree of meiotic multivalent formation is the pollen fertility. Sterile or abnormally sized pollen grains may result from aberrant distribution of homologous chromosomes during meiosis of a pollen mother cell. Oca pollen staining rates as a measure of fertility (Carrión et al., 1995) revealed $20-30 \%$ sterile pollen grains in samples from 86 clonal oca accessions. This rate of abnormal pollen is far higher than that reported for diploid potato (Solanum; $2 n=2 \mathrm{x}=24$ ) species (Trognitz \& Schmiediche, 1993; Trognitz, 1995), in which only $10 \%$ and seldom up to $20 \%$ of the pollen grains are sterile. Therefore, the relatively large percentage of dysfunctional oca pollen corroborates the hypothesis of auto-alloploidy. However, direct cytological comparisons using diploid and polyploid, related Oxalidaceae species have yet to be performed.

Floral morph inheritance studies in other Oxalis species have indicated the possible occurrence of a third factor beside $S$ and $M$ (Leach, 1983; see also Barrett, 1992, p. 7). Our investigation of crosses between three parental oca clones may be too small to detect a putative third factor. On the other hand, the development of a flower involves several genes that are expressed at different levels during different ontogenetic stages. Gene expression is regulated through interaction among these genes and through the environment. A well-studied example are those specific MADS box genes (Schwarz-Sommer et al., 1990) that determine the floral organ identity (Yanofsky, 1995). Genes expressed during early stages of the plant's development may predetermine the expression of genes at later stages (Yanofsky, 1995). Several MADS box genes, such as AP3 in Antirrhinum (Jack et al., 1992) and $P I$ in Arabidopsis (Goto \& Meyerowitz, 1994) have been shown to determine the development of stamens. Their unknown equivalents in Oxalis may also influence the expression of the $S, s$ and $M, m$ factors, which in turn specifically influence the differential development of short, mid, and long styles and stamens.

The data (Table 3 ) suggest that the two factors, $S$ and $M$, segregated independently of each other. To confirm this preliminary result, additional experiments must be made that allow for detection of slight linkage.
No semi-homostyles (Lewis \& Jones, 1992, p. 130) were observed among the progenies of our diallelic crosses involving three parents. However, semi-homostyle M plants were detected by Carrión et al. (1995) among clonal accessions held at the International Potato Centre's gene bank, indicating that oca has the genetic propensity to form such floral variants. The formation of semi-homostyles may depend on specific genetic modifiers which are absent from the three parents used in our experiment.

The number of allelic variants of a single gene may be relatively small in an autoploid when compared to an alloploid species, as fewer ancestors contribute alleles. Therefore, auto-alloploidy of oca may facilitate the conservation of its gene pool in a botanical seed gene bank, as the number of seeds required to be stored to maintain all alleles may be relatively small. Breeding of the crop, however, will be complicated, as desired genotypes may be recovered at a low frequency. Stylar incompatibility restricts the number of successful crosses that can be performed. The apparent maintenance of stylar incompatibility in this polyploid, clonally propagated crop suggests that there might exist strong linkage between the incompatibility gene(s) or mechanism and other, essential functions within the plant. Polyploid species expressing gametophytic incompatibility are frequently self-fertile (Lewis, 1947), whereas diploids that can be produced from tetraploid, self-compatible donors may be self-incompatible (Olsder \& Hermsen, 1976). There are, however, polyploids with intact sporophytic incompatibility, such as the clonally propagated, hexaploid sweet potato (Ipomoea batatas) (Nakanishi \& Kobayashi, 1979). These differences between systems reinforce the proposed polyphyletic origins of stylar incompatibility (see review by Matton et al., 1994), and incompatibility associated with heterostyly is in this respect akin to sporophytic incompatibility.

\section{Acknowledgements}

The German Ministry of Technical Cooperation supported field work through research grants to the International Potato Centre (BMZ project number 94.7860.3-01.100). The collaboration of the German Agency for Technical Cooperation (GTZ) is gratefully acknowledged. The research was carried out as part of the collaborative project on biodiversity of Andean root and tuber crops supported by the Swiss Development Cooperation. We are grateful to Isabel Pallares for raising the oca progenies and recording numerous evaluation data, to Ricardo Rodriguez for technical support of experimentation in the field, and to Miguel Holle for valuable suggestions on the manuscript. 


\section{References}

BARLOW, N. 1923. Inheritance of the three forms in trimorphic species. J. Genet., 13, 133-146.

BARRETT, S. C. H. 1992. Heterostylous genetic polymorphisms: model systems for evolutionary analysis. In: Barrett, S. C. H. (ed.) Evolution and Function of Heterostyly, pp. 1-29. Springer-Verlag, Berlin.

CARRIón, s. 1995. Biología reproductiva de la oca (Oxalis tuberosa Molina) y sus implicaciones para la producción de semilla botánica. Thesis, Pontificia Universidad Católica del Ecuador, Quito, Ecuador.

CARRIÓN, S., HERMANN, M. AND TROGNITZ, B. 1995. La biología reproductiva de la oca (Oxalis tuberosa Molina). Boletín de Lima, 98, 48-68.

DARwIN, C. 1877. The Different Forms of Flowers on Plants of the Same Species. John Murray, London.

DE AZKUE, D. AND MARTínez, A. 1990. Chromosome number of the Oxalis tuberosa alliance (Oxalidaceae). Plant Syst. Evol., 169, 25-29.

ECKERT, C. G. AND BARRETT, S. C. H. 1993. The inheritance of tristyly in Decodon verticillatus (Lythraceae). Heredity, 71, 473-480.

EMSHWILLER, E. AND DOYLE, J. J. 1998a. Evidence for origins of polyploidy of Oxalis tuberosa from chloroplast-expressed glutamine synthetase. Am. J. Bot., 85 (Suppl.), (Proceedings Ann. Meeting Bot. Soc. Am.), abstract no. 362.

EMSHWILlER, E. AND DOYLE, J. J. 1998b. Origins of domestication and polyploidy in oca (Oxalis tuberosa: Oxalidaceae): nrDNA ITS data. Am. J. Bot., 85, 975-985.

FISHER, R. A. AND MATHER, K. 1943. The inheritance of style length in Lythrum salicaria. Ann. Eugen., 12, 1-23.

GOTO, K. AND MEYEROWITZ, E. M. 1994. Function and regulation of the Arabidopsis floral homeotic gene PISTILLATA. Genes Dev., 8, 1548-1560.

JACK, T., BROCKMAN, L. L. AND MEYEROWITZ, E. M. 1992. The homeotic gene APETALA3 of Arabidopsis thaliana encodes a MADS box and is expressed in petals and stamens. Cell, 68, 683-688.
LEACH, C. R. 1983. Fluctuations in heteromorphic self-incompatibility systems. Theor. Appl. Genet., 66, 307-312.

LEWIS, D. 1947. Competition and dominance of incompatibility alleles in diploid pollen. Heredity, 1, 85-108.

LEWIS, D. AND JONES, D. A. 1992. The genetics of heterostyly. In: Barrett, S. C. H. (ed.) Evolution and Function of Heterostyly, pp. 129-150. Springer-Verlag, Berlin.

MATTON, D. P., NASS, N., ClARKE, A. E. AND NEWBigin, E. 1994. Self-incompatibility: How plants avoid illegitimate offspring. Proc. Natl. Acad. Sci. U.S.A., 91, 1992-1997.

NAKANISHI, T. AND KOBAYASHI, M. 1979. Geographic distribution of cross incompatibility groups in sweet potato. Incompatibility Newsl., 11, 72-75.

OLSDER, J. AND HERMSEN, J. G. TH. 1976. Genetics of selfcompatibility in dihaploids of Solanum tuberosum L. I. Breeding behaviour of two self-compatible dihaploids. Euphytica, 25, 597-607.

QUIÑONES, A. M. 1997. Producción controlada de semilla botanica de oca (Oxalis tuberosa Molina; Geraniales: Oxalidaceae) mediante polinización entomófila dirigida. Thesis, Pontificia Universidad Católica, Quito, Ecuador.

SCHWARZ-SOMMER, Z., HUIJSER, P., NACKEN, W., SAEDLER, H. $E T A L$. 1990. Genetic control of flower development by homeotic genes in Antirrhinum majus. Science, 250, 931-936.

TROGNITZ, B. R. 1995. Analysis of pollen tube growth in situ to investigate self-incompatibility in the wild potato Solanum commersonii. Euphytica, 86, 149-156.

TROGNITZ, B. R. AND SCHMIEDICHE, P. E. 1993. A new look at incompatibility relationships in higher plants. Sex Plant Repro., 6, 183-190.

TROGNITZ, B. R., HERMANN, M. AND CARRIÓN, S. 1998. Germplasm conservation of oca (Oxalis tuberosa Mol.) through botanical seed. Seed formation under a system of polymorphic incompatibility. Euphytica, 101, 133-141.

vON UBISCH, G. 1926. Koppelung von Farbe und Heterostylie bei Oxalis rosea. Biol. Zbl., 46, 633-645.

YANOFSKY, M. F. 1995. Floral meristems to floral organs: genes controlling early events in Arabidopsis flower development. Ann. Rev. Plant Physiol. Plant Mol. Biol., 46, 167-188. 